\title{
Preventing Dementia: Shifting Focus Towards Potential Modifiable Risk Factors
}

\author{
Denis Ming'ate Menge ${ }^{1}$, Narayanankutty Nair ${ }^{1}$, Palur Ramakrishnan Anand Vijaya Kumar ${ }^{2, *}$ \\ 'Department of Pharmacy Practice, JSS College of Pharmacy (JSS Academy of Higher Education and Research, Mysuru), Udhagamandalam, The Nilgiris, Tamil Nadu, \\ INDIA. \\ 2Department of Pharmacology, JSS College of Pharmacy (JSS Academy of Higher Education and Research, Mysuru) Udhagamandalam, Tamil Nadu, INDIA.
}

\begin{abstract}
Around the world, 50 million people live with dementia, an incurable disease. The number is expected to surpass 150 million in three decades. The burden on the economy keeps escalating every year. However, encouraging evidence from studies in Europe reveal a decline in rates of incidence dementia. Although the prevalence still remains high, new cases have become fewer. Therefore, research has shifted focus to the role of potential modifiable factors in curbing incidence dementia. Better management of vascular risk factors over the last couple of decades has seen the risk of dementia decrease dramatically. Studies on adherence to Mediterranean diet, moderate alcohol consumption and incorporation of physical activity into daily activities suggest the risk of dementia might be modified in vulnerable population. Smokers should be encouraged and supported to give up the habit. Identification of these potential modifiable risk factors doesn't mean that dementia can eventually be stopped, but this is a start toward decreasing the risk and improving lives of people with dementia. For this review paper, we searched for original articles and review papers in EMBASE and PubMed. Keywords were used individually or in combination
\end{abstract}

in the searches. The keywords used include: dementia, diabetes mellitus, hypertension, Vitamin $B_{12}$ Vitamin $D$, hypercholesterolemia, cognitive reserve, physical activity, physical exercise, smoking, alcohol consumption, Mediterranean diet and hyperhomocysteinemia. We, therefore, review epidemiological longitudinal studies, with a focus on their associations with risk of dementia.

Key words: Cognitive impairment, Dementia, Diabetes mellitus, Mediterranean diet, Physical activity, Risk factors.

\section{Correspondence}

Dr. PR Anand Vijaya Kumar,

Department of Pharmacology, JSS College of Pharmacy, 20, Rocklands, Udhagamandalam. The Nilgiris, Tamil Nadu-643 001, INDIA.

Phone: +9194431 81573

Email: ootyanand2004@gmail.com

DOI: 10.5530/jyp.2019.11.48

\section{INTRODUCTION}

The World Health Organization (WHO) estimates dementia affects 50 million people and this number will triple by the year $2050 .{ }^{1}$ Better standards of living and higher life expectancy mean more people will grow older; however, these elderly individuals are at increased risk of dementia. ${ }^{2}$ This is a reason for concern because dementia still remains incurable. In 2015, the WHO estimated the cost of treatment to be US $\$ 818$ billion $^{1}$ and is expected to increase with the increase in incidence of dementia. Epidemiological studies on secular trends of incidence of dementia, therefore, have huge implication for policy makers in the health sectors.

A two-decade study in Central Sweden reported that prevalence of dementia remained stable between 1897 to 2004, after controlling for age, sex and education. The participants from the Sweden National study on Aging and Care in Kungsholmen (SNAC-K) survived longer than those from Kungsholmen Project (KP) (hazard ratio 0.77, 95\% confidence interval 0.62-0.96). ${ }^{3}$ Interestingly, the Rotterdam study revealed a declining trend in the age-adjusted incidence of dementia rates. The rates were $25 \%$ lower in the subcohort from 2000 when compared to the one from 1990, however, this difference was nonsignificant (incidence ratio $0.75,95 \%$ confidence interval $056-1.02){ }^{4}$ A similar observation was reported by the Zaragoza Study where the prevalence of dementia declined between 1988-89 to 1994-96 (prevalence ratio, 0.75, 95\% confidence interval 0.56-1.02). ${ }^{5}$ Notably, in later subcohorts from both studies, improved control of potential risk factors such as diabetes, ${ }^{6}$ midlife hypertension, ${ }^{7}$ physical inactivity ${ }^{8}$ and smoking ${ }^{9}$ might have influenced the rates of dementia. Moreover, longer survival of dementia patients could mask the declining incidence of dementia.

For instance, Norton et al. estimates that a third of incident Alzheimer's Disease $(\mathrm{AD})$ cases are preventable through potentially modifiable risk factors. For example, low educational attainment posed the highest population attributable risk for $\mathrm{AD}$ worldwide. ${ }^{10}$ Compression of cognitive morbidity through building cognitive reserve and maintaining cognitive stimulation might reduce the burden of dementia on the population at large. ${ }^{11}$ The above studies provide evidence that the course of dementia is malleable. In this review, we focus on identifying those risk factors of dementia that might be modified based on previous population studies.

\section{MATERIALS AND METHODS}

We searched for original articles and review papers in EMBASE and PubMed. Keywords were used individually or in combination in the searches. The keywords used include: Dementia, diabetes mellitus, hypertension, Vitamin $\mathrm{B}_{12}$, Vitamin $\mathrm{D}$, hypercholesterolemia, cognitive reserve, physical activity, physical exercise, smoking, alcohol consumption, Mediterranean diet, hyperhomocysteinemia,

\section{Classic Vascular Risk Factors \\ Diabetes mellitus}

In 2017, the International Diabetes Federation (IDF) estimated that 451 million people were diabetic and will exceed 690 million by $2045 .^{12}$ 
Epidemiological studies have associated diabetes mellitus with increased risk of dementia. ${ }^{13-16} \mathrm{~A}$ cohort of 71,433 diabetes mellitus patients followed for 11 years supports this association. ${ }^{17}$ Diabetes mellitus can accelerate the conversion of Mild Cognitive Impairment (MCI) to dementia. For example, in Kungsholmen Project, MCI patients with diabetes converted to dementia by 4 years earlier than MCI patients without diabetes. ${ }^{18}$ Poor glycemic control may induce vascular dysfunctions leading to cognitive decline. The adjusted hazard ratio of risk of dementia in patients with a longer duration of diabetes is $1.66,95 \%$ CI (1.07-2.26) ${ }^{18}$ However, even newly diagnosed type 2 diabetes mellitus patients are also at an increased risk of dementia (hazard ratio, 1.63; 95\% CI, 1.33-1.99).${ }^{19}$ Higher HbA1c level predicts cognitive decline and brain damage ${ }^{15}$ Further, hypoglycemia can cause subclinical brain damage. A recent meta-analysis suggests that recurrent episodes of severe hypoglycemia impairs memory and processing speed. ${ }^{20}$

A meta-analysis revealed an association between diabetes and risk of dementia in patients with diabetes. ${ }^{21}$ However, not all studies support this association. For instance, the Framingham study failed to find an association between diabetes mellitus and increased risk of incident dementia. ${ }^{22}$ The Tehran Lipid and Glucose Study (TLGS) found an association between diabetes and increased Cardiovascular Events (CVD) ${ }^{23}$ Both cardiovascular events and stroke in type 2 diabetes mellitus accounts for increased risk of conversion of MCI to dementia. ${ }^{16}$ Increase in prevalence of diabetes mellitus can upsurge incidence of dementia, which will be an economic burden especially for low-and middle-income countries. These associations between diabetes and dementia suggest that better glycemic control might reduce the incidence of dementia. Therefore, interventional longitudinal studies with better glycemic control and a longer follow-up period are required to understand the progression of diabetes associated-dementia. Table 1 provides a summary of major longitudinal studies done on diabetes patients whose major outcome was dementia.

\section{Hypertension}

Elevated midlife systolic blood pressure is associated with dementia. ${ }^{30}$ Studies propose various mechanisms of cognitive impairment such as damage of blood-brain barrier via hypoperfusion, ${ }^{31}$ arteriosclerosis and cerebral infarction. ${ }^{32}$ Antihypertensive treatment might reduce the risk of dementia. For example, the randomized controlled trial of Perindopril or Indapamide (ACE inhibitors) reduced the risk of dementia compared to the placebo. ${ }^{33}$ Potassium-sparing diuretics reduced the incidence of dementia in people aged 65 years and older. ${ }^{7}$ In contrast, other studies failed to show a protective action of antihypertensive drugs on cognitive impairment. ${ }^{34,35}$ The results are discordant because of methodological differences including age of onset of hypertension, ${ }^{30}$ age of participants, ${ }^{30}$ duration of follow-up, ${ }^{36}$ different antihypertensive drugs, ${ }^{37,38}$ outcome measures and definitions of cognitive impairment. ${ }^{30,33}$ Though epidemiological studies employ various methodologies, the evidence supports that management of hypertension might modify the risk of dementia.

\section{Hypercholesterolemia}

The relationship between hypercholesterolemia and risk of dementia remains unclear, with some studies revealing an association, ${ }^{39-41}$ lack of association $^{42}$ and a bidirectional relationship. ${ }^{43}$ Interestingly, decreasing cholesterol levels in midlife predict risk of dementia in late-life. ${ }^{42,43}$ However, elevated cholesterol in late-life protects against the risk of dementia. ${ }^{44}$ The age on onset of dyslipidemia might determine the course of dementia. Longitudinal cohort studies of dyslipidemia with different age groups are required to address this controversy.

\section{Modifiable Lifestyle Factors \\ Smoking}

Cigarette smoking increases risk of dementia. ${ }^{45-48}$ Tobacco smoke contains Reactive Oxygen Species (ROS) such as hydrogen peroxide and peroxynitrite. ROS causes oxidative stress in the brain, ${ }^{49}$ and inflammation in rats. $^{50}$ Apart from causing cardiovascular mitochondrial injury and hypertension in mice, ROS is an independent risk factor for dementia. ${ }^{51}$

Dementia risk is greater in smokers without apo E e4 allele than smokers with the apo E e4 allele (relative risk 4.6 [95\% CI 1.5-14.2]). ${ }^{46}$ Smokers age faster than non-smokers and are vulnerable to vascular events and stroke. Smoking is associated with greater brain atrophy ${ }^{52}$ and cancer. ${ }^{53-55}$ Quitting smoking reduces brain atrophy and may prevent cognitive decline. ${ }^{9,56}$

Meta-analyses have confirmed the association between smoking and all-cause dementia for current smokers (RR $1.395 \%$ CI 1.18-1.45), ${ }^{56}$ with greater risk for elderly smokers. Passive smoking also increases risk of dementia, though the association is weak ${ }^{57,58}$ and it impairs prospective memory and executive function. ${ }^{59}$ The risk of dementia increases 3 -fold among passive smokers with carotid artery stenosis. ${ }^{57}$ However, Anhui Study failed to find a positive association between passive smoking and

Table 1: Summary of epidemiological studies of diabetes mellitus and dementia.

\begin{tabular}{|c|c|c|c|c|c|c|c|}
\hline Authors & Study Name (site) & $\begin{array}{c}\text { Age at } \\
\text { baseline } \\
\text { (years) }\end{array}$ & $\begin{array}{l}\text { Follow-up } \\
\text { (years) }\end{array}$ & $\begin{array}{c}\text { Total } \\
\text { population } \\
\text { (with diabetes) }\end{array}$ & $\begin{array}{l}\text { Cognitive } \\
\text { test }\end{array}$ & $\begin{array}{l}\text { Outcome } \\
\text { measured }\end{array}$ & $\begin{array}{c}\text { RR of } \\
\text { dementia } \\
95 \% \mathrm{Cl}\end{array}$ \\
\hline Cheng et al. $2011^{24}$ & Columbia Aging Project (USA) & $\geq 65$ & 9 & $1,488(253)$ & DSM-IV & Dementia & $1.7(1.4-2.9)$ \\
\hline Ahtiluoto et al. $2010^{25}$ & Vantaa $85+$ Study (Finland) & $\geq 85$ & 9 & $553(\mathrm{NR})$ & DSM-III-R & Dementia & NR \\
\hline Akomolafe et al. $2006^{22}$ & Framingham Study (USA) & 70 (mean) & 12.7 & $2,210(202)$ & DSM-IV & Dementia & $2.98(1.0-8.3)$ \\
\hline Peila et al. $2002^{26}$ & $\begin{array}{l}\text { The Honolulu-Asia Aging Study } \\
\text { (USA) }\end{array}$ & $\geq 65$ & 2.9 & $2,574(900)$ & DSM-III-R & Dementia & $1.5(1.0-2.2)$ \\
\hline Honig et al. $2003^{27}$ & $\begin{array}{l}\text { Washington Heights-Inwood } \\
\text { Columbia Aging Project (USA) }\end{array}$ & $\geq 65$ & 7 & $1,766(\mathrm{NR})$ & DSM-IV & Dementia & $1.6(1.0-2.4)$ \\
\hline Xu et al. $2004^{28}$ & Kungsholmen Project (Sweden) & $\geq 75$ & 6 & 1,301 & DSM-III-R & Dementia & $1.5(1.0-2.1)$ \\
\hline MacKnight et al. $2002^{29}$ & $\begin{array}{c}\text { Canadian Study of Health and } \\
\text { Aging (Canada) }\end{array}$ & $\geq 65$ & 5 & 5,574 & DSM-III-R & Dementia & NA \\
\hline Ott et al. $1999^{6}$ & $\begin{array}{l}\text { The Rotterdam Study (The } \\
\text { Netherlands) }\end{array}$ & $\geq 55$ & 2.1 & $6,370(692)$ & DSM-III-R & Dementia & $1.9(1.2-2.8)$ \\
\hline
\end{tabular}

DSM-III-R, Diagnostic and Statistical Manual of Mental Disorders, $3^{\text {rd }}$ edition, revised for Dementia; DSM-IV, Diagnostic and Statistical Manual of Mental Disorders, $4^{\text {th }}$ edition for dementia; NA, no association; NR, Not reported. 
moderate dementia syndromes. ${ }^{60}$ Most studies reiterate that active or passive smoking is detrimental to cognition. Smoking cessation programme should be promoted within communities to address the risk of dementia.

\section{Alcohol consumption}

The association between alcohol and dementia is debatable. In the CONOR study involving 25,635 participants, elderly abstainers were at high risk of dementia related deaths ${ }^{61}$ In addition to total abstinence, excessive alcohol consumption also increases the risk of dementia. ${ }^{62,63}$ The Whitehall II cohort study that followed 9087 participants over 23 years found consuming more than 14 units of alcohol per week increased the risk of dementia by $17 \%{ }^{64}$ In contrast, a review of 143 studies proposed moderate or light consumption of alcohol reduces the risk of dementia in older people. ${ }^{65}$ Nevertheless, low or risky consumption failed to find association with dementia. ${ }^{66}$

Light to moderate alcohol consumption may lower cardiovascular risk, increase brain blood flow, modulate vasodilation of blood vessels and reduce inflammation. ${ }^{67}$ Late-life alcohol consumption preserves hippocampal volume. Late-life abstainers have comparatively lesser brain volume than their peers who are moderate drinkers. ${ }^{68}$ However, in Whitehall II cohort study in community-dwelling adults, moderate alcohol consumption had increased risk of hippocampal atrophy. ${ }^{69}$
Longitudinal studies propose a u-shaped association between alcohol consumption and cognitive outcomes. ${ }^{70}$

The effects of alcohol on dementia may depend on amount of alcohol, type of alcohol and the age of consumption. Though suggested moderate alcohol consumption is beneficial, its overall effect on health has to be weighed. Nevertheless, alcohol consumption as a means to prevent dementia should be carefully considered. Table 2 summarizes epidemiological studies linking alcohol consumption and dementia.

\section{Hyperhomocysteinemia}

Homocysteine in serum is determined by Vitamin $B_{12}$ levels and age of the individual. ${ }^{73}$ Few studies associated elevated homocysteine levels and cognitive impairment. ${ }^{74,75}$ Seshadri et al. found that hyperhomocysteinemia was an independent predictor of dementia. ${ }^{76}$ Alzheimer's patients have hyperhomocysteinemia. ${ }^{77} \mathrm{~A}$ meta-analysis by Wald and colleagues including eight prospective cohort studies with 8669 participants and a mean follow-up period of 5 years established serum homocysteine was associated with incidence dementia. However, the cause-effect could not be established from the meta-analysis. ${ }^{78}$ Therefore, it seems Vitamin $\mathrm{B}_{12}$ supplementation to $\mathrm{AD}$ patients might lower homocysteine levels consequently preventing further cognitive decline. However, the relationship between them is complicated with longitudinal studies yielding discordant results. $^{79}$

Table 2: Summary of epidemiological studies of alcohol consumption and dementia.

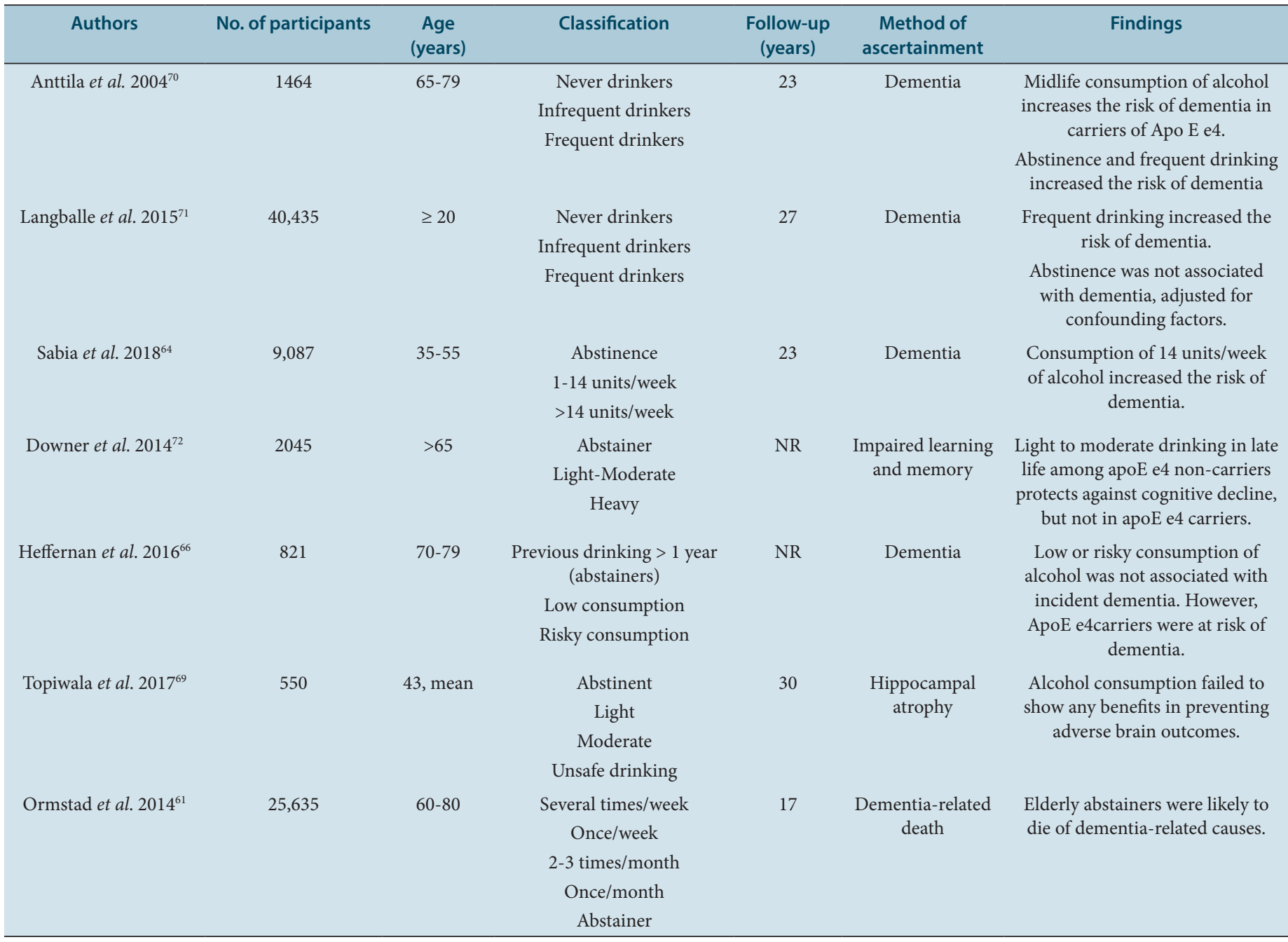




\section{Vitamin $B_{12}$ deficiency}

Cyanocobalamin is essential for brain development and functioning. ${ }^{80}$ It is mainly sourced from animal foods. Therefore, vegetarians ${ }^{81}$ and elderly people ${ }^{82}$ are at risk of Vitamin $B_{12}$ deficiency. Vitamin $B_{12}$ deficient individuals are at risk of cognitive impairment. ${ }^{83}$ It elevates brain homocysteine levels, an independent risk factor for cognitive impairment. ${ }^{84,85}$ However, randomized controlled trials failed to find benefits of Vitamin $\mathrm{B}_{12}$ supplementation on cognition. ${ }^{86,87}$ A systematic review in 2012 also observed a similar outcome. ${ }^{88}$ It suggests Vitamin $B_{12}$ associated dementia can be addressed by consuming animal sourced foods. But the quantity and type of animal-based diet for preventing cognitive impairment requires further research.

\section{Vitamin D deficiency}

Vitamin $\mathrm{D}$ is of two types: Vitamin $\mathrm{D}_{2}$ and $\mathrm{D}_{3}$; found in diet and synthesized in the human skin, respectively. 1, 25-dihydroxy Vitamin $\mathrm{D}_{3}$ receptor and $1 \alpha$-hydroxylase essential for synthesis of the active form of Vitamin D, are expressed in the hippocampus and dentate gyrus. ${ }^{89}$ Neural cells require the active form of Vitamin D (1,25-dihydroxy-Vitamin $\mathrm{D}_{3}$ ) for their development and functioning. The active form of Vitamin D modulates neurotrophin expression and reduces cytotoxicity and death of neurons. Levels of 25-hydroxyvitamin D below $50 \mathrm{nmol} / \mathrm{L}$ increase the risk of development of all-cause dementia up to 6 folds when compared to sufficient levels..$^{90,91}$ On the contrary, a study involving 4809 participants failed to find an association between Vitamin D deficiency and cognitive impairment. ${ }^{92}$ Little Johns et al. suggest a threshold of $50 \mathrm{nmol} / \mathrm{L}$ during Vitamin D supplementation, to show benefits against cognitive decline.

Table 3: Summary of epidemiological studies of physical activity and dementia.

\begin{tabular}{|c|c|c|c|c|c|c|c|}
\hline Study & $\begin{array}{l}\text { Sample } \\
\text { size }\end{array}$ & $\begin{array}{c}\text { Age } \\
\text { (years) }\end{array}$ & $\begin{array}{l}\text { Follow-up } \\
\text { (years) }\end{array}$ & Type of study & Inclusion criteria & Intervention & Outcome \\
\hline Zhou et al. $2017^{111}$ & 7,501 & $>65$ & 9 & $\begin{array}{l}\text { Prospective } \\
\text { cohort study }\end{array}$ & Dementia-free & PE & $\begin{array}{l}\text { Regular PE decreased the } \\
\text { risk of dementia }\end{array}$ \\
\hline Sink et al. $2015^{112}$ & 1,635 & $70-89$ & 2 & $\begin{array}{l}\text { Randomized } \\
\text { controlled trial }\end{array}$ & $\begin{array}{c}\text { Dementia-free } \\
\text { sedentary elderly adults }\end{array}$ & PE vs HE & $\begin{array}{l}\text { Moderate PA was not } \\
\text { associated with decreased } \\
\text { risk of dementia }\end{array}$ \\
\hline $\begin{array}{l}\text { Lautenschlager et al. } \\
\qquad 2008^{113}\end{array}$ & 170 & $>50$ & 1.5 & $\begin{array}{l}\text { Randomized } \\
\text { controlled trial }\end{array}$ & $\begin{array}{l}\text { dementia-free with } \\
\text { subjective memory } \\
\text { complaints }\end{array}$ & PA & $\begin{array}{l}\text { Modest improvement in } \\
\text { cognitive function }\end{array}$ \\
\hline $\begin{array}{l}\text { Scarmeas et al. } \\
2011^{102}\end{array}$ & 357 & $>65$ & 5.2 & $\begin{array}{l}\text { Prospective } \\
\text { cohort study }\end{array}$ & Dementia-free at baseline & $\mathrm{PA}$ & $\begin{array}{l}\text { PA decreases the risk of } \\
\text { dementia and dementia- } \\
\text { related mortality in } \mathrm{AD} \\
\text { patients }\end{array}$ \\
\hline Gross et al. $2017^{114}$ & 646 & $38-63$ & 30 & $\begin{array}{l}\text { Prospective } \\
\text { cohort study }\end{array}$ & Dementia-free & $\mathrm{PA}$ or PE & $\begin{array}{l}\text { Physical activity is not } \\
\text { associated with decreased } \\
\text { risk of dementia }\end{array}$ \\
\hline Tan et al. $2017^{115}$ & 5,701 & $>60$ & 10 & $\begin{array}{l}\text { Prospective } \\
\text { cohort study }\end{array}$ & Dementia-free & $\mathrm{PA}$ & $\begin{array}{c}\text { Low PA increased the risk } \\
\text { of dementia }\end{array}$ \\
\hline Sabia et al. $2017^{116}$ & 10,308 & $35-55$ & $\begin{array}{c}27 \\
\text { mean }\end{array}$ & $\begin{array}{l}\text { Prospective } \\
\text { cohort study }\end{array}$ & Dementia-free & PA & $\begin{array}{l}\text { PA is not associated with } \\
\text { risk of cognitive decline } \\
\text { or dementia }\end{array}$ \\
\hline Andel et al. $2008^{104}$ & 3,134 & $\begin{array}{c}48.1 \text { mean } \\
\text { at baseline } \\
79.5 \text { at } \\
\text { follow-up }\end{array}$ & 31 & $\begin{array}{l}\text { Prospective } \\
\text { cohort study }\end{array}$ & Dementia-free & $\mathrm{PE}$ & $\begin{array}{l}\text { Midlife PE may reduce } \\
\text { the risk of dementia in } \\
\text { late-life }\end{array}$ \\
\hline $\begin{array}{c}\text { De Bruijn et al. } \\
2013^{117}\end{array}$ & 4,406 & $61-97$ & 14 & $\begin{array}{l}\text { Prospective } \\
\text { cohort study }\end{array}$ & Dementia-free & $\mathrm{PA}$ & $\begin{array}{l}\text { PA is associated with } \\
\text { decreased risk of } \\
\text { dementia, limited to a } \\
\text { follow-up period of } 4 \\
\text { years }\end{array}$ \\
\hline Chang et al. $2010^{103}$ & 4,945 & 51 mean & 26 & $\begin{array}{l}\text { Prospective } \\
\text { cohort study }\end{array}$ & Dementia-free & $\mathrm{PA}$ & $\begin{array}{l}\text { PA in midlife is } \\
\text { associated with a reduced } \\
\text { risk of dementia in } \\
\text { late-life. }\end{array}$ \\
\hline $\begin{array}{c}\text { Kishimoto et al. } \\
2016^{118}\end{array}$ & 803 & $>65$ & 17 & $\begin{array}{l}\text { Prospective } \\
\text { cohort study }\end{array}$ & Dementia-free & $\mathrm{PA}$ & $\begin{array}{l}\text { PA in midlife may reduce } \\
\text { the risk of cognitive } \\
\text { decline in late-life. }\end{array}$ \\
\hline $\begin{array}{l}\text { Buchman et al. } \\
2012^{119}\end{array}$ & 716 & 81.6 mean & 4 & $\begin{array}{l}\text { Prospective } \\
\text { cohort study }\end{array}$ & Dementia-free & $\mathrm{PA}$ & $\begin{array}{l}\text { Higher level PA may } \\
\text { reduce the risk of } \\
\text { dementia }\end{array}$ \\
\hline
\end{tabular}

PA, physical activity; PE, physical exercise; HE, health education. 


\section{Protective Factors}

\section{Cognitively training/exercise}

Cognitive training improves specific cognitive domains or functions. ${ }^{93}$ A systematic review of 35 studies on cognitive training improves general cognitive functions. ${ }^{94}$ Cognitive training alters cortical thickness. ${ }^{95}$ In an interventional study combining physical activity and cognitive training in dosages ranging from 24 to 110 sessions, global cognitive functions improves in a dose-dependent manner However, these benefits are not seen in elderly people with Neurocognitive Disorders (NCDs).$^{96}$ In healthy elderly Italian population study, low-intensity multi-domain cognitive exercises enhances executive functions and short-term memory. ${ }^{97}$ Multiple-domain cognitive training ameliorates general cognition, visuospatial abilities and delayed memory, while single-domain enhances attention and executive functions. ${ }^{98}$

Most studies reveal improvement in specific cognitive domains with cognitive training. However, these studies vary in; duration of intervention, number of participants and type of cognitive exercises, hence, interpretation of the findings should be done with caution. ${ }^{99,100}$ Further, future research should look into long-term benefits of cognitive training, suitable age for commencing training and impact technology-driven training in cognition.

\section{Physical exercise/activities}

Physical exercises and activities increase energy expenditure in the body. ${ }^{101}$ Physical exercise improves cerebral flow, production of brainderived neurotrophic factor and neurogenesis. Studies reveal an association between physical activity and dementia. ${ }^{102}$ Midlife physical activity prevents late-life dementia. ${ }^{103,104}$ Notably, leisure-time physical activity in midlife decreases the risk of late-life dementia. ${ }^{105}$ The intensity and timing of physical activity influences strength of this association. ${ }^{106,107}$ Aerobic exercises prevent hippocampal atrophy in older adults. ${ }^{108}$ However, meta-analyses contradict positive impact of exercise on dementia. For example, meta-analysis of five RCTs failed to find an association between long-term exercise and dementia. ${ }^{109} \mathrm{~A}$ Cochrane systematic review also found aerobic exercises failed to improve cognitive function in elderly individuals. ${ }^{110}$ Methodologic variations such as duration, intensity and type of exercise and outcome measures of dementia might be the reason for these contradictions. Physical activity should be encouraged considering its impact in general well-being. Table 3 gives a summary of epidemiological studies of physical activities and their influence on dementia.

\section{Mediterranean diet}

The mediterranean diet includes plenty of vegetables, fruits, nuts, wholegrain cereals, fish and less quantity of meat and dairy products along with moderate alcohol intake and unsaturated fats. ${ }^{120}$ Growing evidence suggests that Mediterranean diet prevents dementia, ${ }^{121,122}$ but, this association is inconclusive. ${ }^{123,124}$ Hellenic Longitudinal Investigation of Ageing and Diet (HELIAD) participants on Mediterranean diet performed better in cognitive tests and had lower dementia rates. ${ }^{125}$ It might be due to cumulative effect of the food, as opposed to individual food components. ${ }^{126}$ Recently, increased interest on how diet affects cognition has come to the fore. Some studies have focused solely on the individual components of Mediterranean diet such as fish, ${ }^{127-130}$ leafy vegetables ${ }^{131,132}$ and fruits. ${ }^{133-135}$ High fish intake prevents brain atrophy. ${ }^{136}$ Mediterranean diet is associated with a decrease in cardiovascular diseases - an independent risk factor for dementia. ${ }^{137}$ However, Mediterranean diet failed to prevent cognitive decline in women with cardiovascular disease. ${ }^{138}$ Effects of Mediterranean diet in different ethnicities should be explored further. Long-term follow-up of the same can pave ways for prevention therapies using diet.

\section{CONCLUSION}

Identification of potentially modifiable factors will not cure dementia. These factors serve the purpose to decrease incidence of dementia. The complex relationship between multiple risk factors and dementia render findings from most studies inconclusive. Results from the studies above support the concept that risk of dementia can be modified by incorporating changes in lifestyle as well as better management of classic vascular risk factors. The recent longitudinal studies from Europe as well as the USA reveal a drop in the number of incident dementia cases. Better management of hypertension, diabetes and stroke, may have had an impact on the prevalence of dementia, because of longer survival times. Available data on moderate drinking of alcohol does not entirely support the idea of abstainers taking up to drinking. Additionally, quitting smoking has other benefits, besides preventing cognitive decline, for example, decreased the risk of cancer in ex-smokers or non-smokers. Leisure activities and physical exercises are also beneficial in decreasing the risk of dementia and cardiovascular events. Socially active individuals tend to have a decreased risk of dementia. With the lack of drugs to stop dementia, physicians may have to rely on modifiable risk factors to alter the course of the disease and curb incident cases.

\section{ACKNOWLEDGEMENT}

We are grateful to Dr. Yasam Venkata Ramesh for his comments on a previous draft.

\section{CONFLICT OF INTEREST}

The authors declare no competing interests.

\section{ABBREVIATIONS}

ACE inhibitors: Acetylcholinesterase inhibitors; AD: Alzheimer's disease; ADDTC: Alzheimer Disease Diagnostic and Treatment Center for Vascular Dementia; CONOR study: Cohort of Norway Study; DSM-III-R: Diagnostic and Statistical Manual of Mental Disorders, $3^{\text {rd }}$ edition, revised for Dementia; DSM-IV: Diagnostic and Statistical Manual of Mental Disorders, $4^{\text {th }}$ edition for dementia; FHS study: Framingham Heart Study; GMS: Geriatric Mental Scale; HELIAD study: the Hellenic Longitudinal Investigation of Ageing and Diet Study; IDF: International Diabetes Federation; MAS study: The Sydney Memory and Ageing Study; MCI: Mild cognitive impairment; MMSE: Mini-mental state Examination; MoCA: Montreal Cognitive Assessment Scale; NCDs: Neurocognitive disorders (NCDs); NINCDS-ADRDA: National Institute of Neurological and Communicative Diseases and Stroke/ Alzheimer's Disease and Related Disorders Association for Alzheimer's disease; RCT: Randomized controlled trial; TLGS: Tehran Lipid and Glucose Study; WHO: World Health Organization.

\section{REFERENCES}

1. World Health Organization. Dementia [Internet]. 2019 [cited 2019 Mar 26] Available from: https://www.who.int/news-room/fact-sheets/detail/dementia

2. Najar J, Ostling S, Gudmundsson P, Sundh V, Johansson L, Skoog I, et al. Cognitive and Physical activity and Dementia: A 44-year longitudinal population study of women. Neurology. 2019;92(12):e1-9.

3. Qiu C, Strauss EV, Bäckman L, Winblad B, Fratglioni L. Twenty-year changes in dementia occurrence suggest decreasing incidence in central Stockholm, Sweden. Neurology. 2013;80(20):1888-94

4. Schrijvers EMC, Verhaaren BFJ, Koudstaal PJ, Hofman A, Ikram MA, Breteler MMB. Is dementia incidence declining? Trends in dementia incidence since 1990 in the Rotterdam Study. Neurology. 2012;78(19):1456-63.

5. Lobo A, Saz P, Marcos G, Dia JL, Ventura T, Montanes JA, et al. Prevalence of dementia in a southern European population in two different time periods: The ZARADEMP Project. Acta Psychiatr Scand. 2007;116(4):299-307.

6. Ott A, Stolk RP, Harskamp FV, Pols HAP, Hofman A, Breteler MMB. Diabetes mellitus and the risk of dementia: The Rotterdam Study. Neurology. 
1999;53(9):1937-42.

7. Corrada MM, Hayden KM, Paganini-Hill A, Bullain SS, Demoss J, Aguirre C, et al. Age of Onset of Hypertension and Risk of Dementia in the Oldest-Old: The 90+ Study. Alzheimer's Dement. 2018;13(2):103-10.

8. Erickson KI, Raji CA, Lopez OL, Becker JT, Rosano C, Newman AB, et al. Physical activity predicts gray matter volume in late adulthood: The Cardiovascular Health Study. Neurology. 2010;75(16):1415-22

9. Choi D, Choi S, Park SM. Effect of smoking cessation on the risk of dementia: a longitudinal study. Ann Clin TransI Neurol. 2018;5(10):1192-9.

10. Norton S, Matthews FE, Barnes DE, Yaff K, Brayne C. Potential for primary prevention of Alzheimer's disease: an analysis of population-based data. Lancet Neurol. 2014:13(8):788-94.

11. Langa KM, Larson EB, Karlawish JH, Cutler DM, Kabeto MU, Kim SY, et al. Trends in the Prevalence of Mortality of Cognitive impairment in the United States: Is There Evidence of a Compression of Cognitive Morbidity?. Alzheimer's Dement. 2009;4(2):134-44.

12. Cho NH, Shaw JE, Karuranga S, Huang Y, Rocha JD, Ohlrogge AW, et al. IDF Diabetes Atlas: Global estimates of diabetes prevalence for 2017 and projections for 2045. Diabetes Res Clin Pract. 2018;138:271-81.

13. Gorska-Ciebiada M, Saryusz-Wolska M, Borkowska A, Ciebiada M, Loba J. Adiponectin, leptin and IL-1 $\beta$ in elderly diabetic patients with mild cognitive impairment. Metab Brain Dis. 2016;31(2):257-66

14. Cukierman-Yaffe T, Gerstein HC, Lazar RM, Lovato L, Miller ME, Coker LH, et al. Relationship Between Baseline Glycemic Control and Cognitive Function in Individuals With Type 2 Diabetes and Other Cardiovascular Risk Factors. Diabetes Care. 2009;32(2):221-6.

15. Nguyen HT, Grzywacz JG, Arcury TA, Chapman C, Kirk JK, Ip EH, et al. Linking Glycemic Control and Executive Function in Rural Older Adults with Diabetes. J Am Geriatr Soc. 2010;58(6):1123-7.

16. Albai O, Frandes M, Timar R, Roman D, Timar B. Risk factors for developing dementia in type 2 diabetes mellitus patients with mild cognitive impairment. Neuropsychiatr Dis Treat. 2019;15:167-75.

17. Huang C, Chung C, Leu H, Lin L, Chiu CC, Hsu CY, et al. Diabetes Mellitus and the Risk of Alzheimer's Disease: A Nationwide Population-Based Study. PLoS One. 2014;9(1):e87095.

18. Ma F, WuT, Miao R, Zhang W, Huang G. Conversion of Mild Cognitive Impairment to Dementia among Subjects with Diabetes: A Population-Based Study of Incidence and Risk Factors with Five Years of Follow-up. J Alzheimer's Dis. 2015;43(4):1441-9.

19. Cheng P, Sy H, Wu S, Wang W, Chen Y. Newly diagnosed type 2 diabetes and risk of dementia: A population-based 7-year follow-up study in Taiwan. J Diabetes Complications. 2012;26(5):382-7.

20. Chen YX, Liu ZR, Yu Y, Yao ES, Liu XH, Liu L. Effect of recurrent severe hypoglycemia on cognitive performance in adult patients with diabetes: A meta-analysis. J Huazhong Univ Sci Technol Med Sci. 2017;37(5):642-8.

21. Zhang J, Chen $C$, Hua S, Liao H, Wang M, Xiong Y, et al. An updated MetaAnalysis of cohort studies: Diabetes and risk of Alzheimer's disease. Diabetes Res Clin Pract. 2017;124:41-7.

22. Akomolafe A, Beiser A, Meigs JB, Au R, Green RC, Farrer LA, et al. Diabetes Mellitus and Risk of Developing Alzheimer Disease: Results From the Framingham Study. Arch Neurol. 2006;63(11):1551-5.

23. Ramezankhani A, Harati H, Bozorgmanesh M, Tohidi M, Azizi F, Hadaegh F Diabetes Mellitus: Findings from 20 Years of the Tehran Lipid and Glucose Study. Int J Endocrinol Metab. 2018;16(4 Suppl):e84784.

24. Cheng D, Noble J, Tang MX, Schupf N, Mayeux R, Luchsinger JA. Type 2 Diabetes and Late-Onset Alzheimer's Disease. Dement Geriatr Cogn Disord. 2011;31(6):424-30.

25. Ahtiluoto S, PolvikoskiT, Peltonen M, Solomon A, Tuomilehto J, Winblad B, et al. Diabetes, Alzheimer disease and vascular dementia: A population-based neuropathologic study. Neurology. 2010;75(13):1195-202

26. Peila R, Rodriguez BL, Launer LJ. Type 2 Diabetes, APOE Gene and the Risk for Dementia and Related Pathologies. Diabetes. 2002;51(4):1256-62.

27. Honig LS, Tang MX, Albert S, Costa R, Luchsinger J, Manly J, et al. Stroke and the Risk of Alzheimer Disease. Arch Neurol. 2003;60(12):1707-12.

28. Xu WL, Qiu CX, Wahlin $\AA$, Winblad B, Fratiglioni L. Diabetes mellitus and risk of dementia in the Kungsholmen project: A 6-year follow-up study. Neurology 2004;63(7):1181-6.

29. MacKnight C, Rockwood K, Erin A, McDowell I. Diabetes mellitus and the Risk of Dementia, Alzheimer's Disease and Vascular Cognitive Impairment in the Canadian Study of Health and Aging. Dement Geriatr Cogn Disord. 2002;14(2):77-83

30. Gottesman RF, Schneider ALC, Albert M, Alonso A, Bandeen-Roche K, Coker L, et al. Midlife Hypertension and 20-Year Cognitive Change The Atherosclerosis Risk in Communities Neurocognitive Study. JAMA Neurol. 2014;71(10):1218-27.

31. Choi JY, Cui Y, Kim BG. Interaction Between Hypertension and Cerebral Hypoperfusion in the Development of Cognitive Dysfunction and White Matter Pathology in Rats. Neuroscience. 2015;303:115-25.

32. Graff-Radford J, Raman MR, Rabinstein AA, Przybelski SA, LesnickTG, Boeve BF, et al. Association Between Microinfarcts and Blood Pressure Trajectories JAMA Neurol. 2018;75(2):212-8.

33. Tzourio C, Anderson C, Chapman N, Woodward M, Neal B, MacMahon S, et al. Effects of Blood Pressure Lowering With Perindopril and Indapamide Therapy on Dementia and Cognitive Decline in Patients With Cerebrovascular Disease. Arch Intern Med. 2003;163(9):1069-75.

34. Applegate WB, Pressel S, Wittes J, Luhr J, Shekelle RB, Camel GH, et al. Hypertension on Behavioral Variables Impact of the Treatment of Isolated Systolic: Results From the Systolic Hypertension in the Elderly Program. Arch Intern Med. 1994;154(19):2154-60.

35. Forette F, Seux M, Staessen JA, Thiis L, Birkenhäger WH, Babarskiene M, et al. Prevention of dementia in randomised double-blind placebo-controlled Systolic Hypertension in Europe (Syst-Eur) trial. Lancet. 1998;352(9137):1347-51.

36. Launer LJ, Ross GW, Petrovitch H, Masaki K, Foley D, White LR, et al. Midlife blood pressure and dementia: the Honolulu-Asia aging study. Neurobiol Aging. 2000;21(1):49-55

37. Hajjar I, Brown L, Mack WJ, Chui H. Impact of Angiotensin Receptor Blockers on Alzheimer Disease Neuropathology in a Large Brain Autopsy Series. Arch Neurol. 2012;69(12):1632-8.

38. Khachaturian AS, Zandi PP, Lyketsos CG, Hayden KM, Skoog I, Norton MC, et al. Antihypertensive Medication Use and Incident Alzheimer Disease: The Cache County Study. Arch Neurol. 2006;63(5):686-92.

39. Dufouil C, Richard F, Fiévet N, Dartigues JF, Ritchie K, Tzourio C, et al. APOE genotype, cholesterol level, lipid-lowering treatment and dementia: The ThreeCity Study. Neurology. 2005;64(9):1531-8.

40. Whitmer RA, Sidney S, Selby J, Whitmer RA, Sidney S, Selby J, et al. Midlife cardiovascular risk factors and risk of dementia in late life. Neurology. 2005;64(2):277-81

41. Kivipelto M, Helkala E, Hänninen T, Laakso MP, Hallikainen M, Alhainen $\mathrm{K}$, et al. Midlife vascular risk factors and late-life mild cognitive impairment: A population-based study. Neurology. 2001;56(12):1683-90

42. Mielke MM, Zandi PP, Shao H, Waern M, Ostling S, Guo X, et al. The 32-year relationship between cholesterol and dementia from midlife to late life. Neurology. 2010;75(21):1888-95

43. Solomon A, Kåreholt I, Ngandu T, Winblad B, Nissinen A, Tuomilehto J, et al. Serum cholesterol changes after midlife and late-life cognition: Twenty-one-year follow-up study. Neurology. 2007;68(10):751-6.

44. Mielke MM, Zandi PP, Sjögren M, Gustafson D, Östling S, Steen B, et al. High total cholesterol levels in late life associated with a reduced risk of dementia. Neurology. 2005;64(10):1689-95.

45. Ohara T, Ninomiya T, Hata J, Ozawa M, Yoshida D, Mukai N, et al. Midlife and Late-Life Smoking and Risk of Dementia in the Community: The Hisayama Study. J Am Geriatr Soc. 2015;63(11):2332-9.

46. Ott A, Slooter AJC, Hofman A, Harskamp FV, Witteman JCM, Broeckhoven CV, et al. Smoking and risk of dementia and Alzheimer's disease in a populationbased cohort study: The Rotterdam Study. Lancet. 1998;351(9119):1840-3.

47. Doll R, Peto R, Boreham J, Sutherland I. Smoking and dementia in male British doctors: Prospective study. BMJ. 2000;320(7242):1097-102.

48. Zhou S, Zhou R, Zhong T, Li R, Tan J, Zhou H. Association of Smoking and Alcohol Drinking with Dementia Risk Among Elderly Men in China. Curr Alzheimer's Res. 2014;11 (9):899-907.

49. Peluffo G, Calcerrada P, Piacenza L, Pizzano N, Radi R. Superoxide-mediated inactivation of nitric oxide and peroxynitrite formation by tobacco smoke in vascular endothelium: studies in cultured cells and smokers. Am J Physiol Circ Physiol. 2009;296(6):H1781-92.

50. Gentner NJ, Weber LP. Secondhand tobacco smoke, arterial stiffness and altered circadian blood pressure patterns are associated with lung inflammation and oxidative stress in rats. Am J Physiol Circ Physiol. 2012;302(3):H818-25.

51. Dikalov S, Itani H, Richmond B, Vergeade A, Rahman SMJ, Boutaud O, et al. Tobacco Smoking Induces Cardiovascular Mitochondrial Oxidative Stress, Promotes Endothelial Dysfunction and Enhances Hypertension. Am J Physiol Circ Physiol. 2019;316(3):H639-46.

52. Karama S, Ducharme S, Corley J, Starr JM, Wardlaw JM, Bastin ME, et al. Cigarette smoking and thinning of the brain's cortex. Mol Psychiatry. 2015;20(6):778-85

53. Beynon RA, Lang S, Schimansky S, Penfold CM, Waylen A, Pawlita M, et al Tobacco smoking and alcohol drinking at diagnosis of head and neck cancer and all-cause mortality: Results from head and neck 5000, a prospective observational cohort of people with head and neck cancer. Int J Cancer. 2018;143(5):1114-27.

54. Kuper H, Adami H, Boffetta P. Tobacco use, cancer causation and public health impact. J Intern Med. 2002;251 (6):455-66.

55. Stämpfli MR, Anderson GP. How cogarette smoke skews immune responses to promote infection, lung disease and cancer. Immunology. 2009;9(5):377-84.

56. Zhong G, Wang Y, Zhang Y, Guo JJ, Zhao Y. Smoking Is Associated with an Increased Risk of Dementia: A Meta-Analysis of Prospective Cohort Studies with Investigation of Potential Effect Modifiers. PLoS One. 2015;10(3):e0118333.

57. Barnes DE, Haight TJ, Mehta KM, Carlson MC, Kuller LH, Tager IB. Secondhand Smoke, Vascular Disease and Dementia Incidence: Findings From the Cardio- 
vascular Health Cognition Study. Am J Epidemiol. 2010;171(3):292-302.

58. Stirland LE, Shea ClO, Russ TC. Passive smoking as a risk factor for dementia and cognitive impairment: systematic review of observational studies. Int Psychogeriatrics. 2018;30(8):1177-87.

59. Heffernan TM, O'Neill TS. Everyday Prospective Memory and Executive Function Deficits Associated with Exposure to Second-Hand Smoke. J Addict. 2013;2013:160486.

60. Chen R, Wilson K, Chen Y, Zhang D, Qin X, He M, et al. Association between environmental tobacco smoke exposure and dementia syndromes. Occup Environ Med. 2013;70(1):63-9.

61. Ormstad H, Rosness TA, Bergem MLA, Bjertness E, Strand BH. Alcohol consumption in the elderly and risk of dementia related death-A Norwegian prospective study with a 17-year follow-up. Int J Neurosci. 2014;126(2):135-44.

62. Reas ET, Laughlin GA, Barrett-Connor E, Mcevoy LK. Moderate, Regular Alcohol Consumption is Associated with Higher Cognitive Function in Older Communuty-Dwelling Adults. J Prev ALzheimer's Dis. 2016;3(2):105-13.

63. Lang I, Wallace RB, Huppert FA, Melzer D. Moderate alcohol consumption in older adults is associated with better cognition and well-being. Age Ageing. 2007;36(3):256-61.

64. Sabia S, Fayosse A, Dumurgier J, Dugravot A, Akbaraly T, Britton A, et al. Alcoho consumption and risk of dementia: 23 year follow-up of Whitehall II cohort study. BMJ. 2018;362:k2927.

65. Neafsey E, Collins M. Moderate alcohol consumption and cognitive risk. Neuropsychiatr Dis Treat. 2011;7:465-84

66. Heffernan M, Mather KA, Xu J, Assareh AA, Kochan NA, Reppermund S, et al. Alcohol Consumption and Incident Dementia: Evidence from the Sydney Memory and Ageing Study. J Alzheimer's Dis. 2016;52(2):529-38.

67. Snow WM, Murray R, Ekuma O, Tyas SL, Barnes GE. Alcohol use and cardiovascular health outcomes: A comparison across age and gender in the Winnipeg Health and Drinking Survey Cohort. Age Ageing. 2009;38(2):206-12.

68. Downer B, Jiang Y, Zanjani F, Fardo D. Effects of Alcohol Consumption on Cognition and Regional Brain Volumes Among Older adults. Am J Alzheimers Dis Other Demen. 2015;30(4):364-74.

69. Topiwala A, Allan CL, Valkanova V, Filippini N, Sexton C, Mahmood A, et al. Moderate alcohol consumption as risk factor for adverse brain outcomes and cognitive decline: Longitudinal cohort study. BMJ. 2017;357:j2353.

70. Anttila T, Helkala E, Viitanen $M$, Kåreholt I, Fratiglioni L, Winblad $B$, et al. Alcohol drinking in middle age and subsequent risk of mild cognitive impairment and dementia in old age: A prospective population based study. BMJ. 2004;329(7465):539.

71. Langballe EM, Ask H, Holmen J, Stordal E, Saltvedt I, Selbaek G, et al. Alcohol consumption and risk of dementia up to 27 years later in a large, populationbased sample: The HUNT study, Norway. Eur J Epidemiol. 2015;30(9):1049-56.

72. Downer B, Zanjani F, Fardo DW. The Relationship Between Midlife and Late Life Alcohol Consumption, APOE e4 and the Decline in Learning and Memory Among Older Adults. Alcohol Alcohol. 2014;49(1):17-22.

73. Smith $A D$, Refsum $H$, Bottiglieri T, Fenech $M$, Hooshmand $B$, McCaddon $A$, et al. Homocysteine and Dementia: An International Consensus Statement. J Alzheimer's Dis. 2018;62(2):561-70.

74. Clarke R, Smith AD, Jobst KA, Refsum H, Sutton L, Ueland PM. Folate, Vitamin $B_{12}$ and Serum Total Homocysteine Levels in Confirmed Alzheimer Disease. Arch Neurol. 1998;55(11):1449-55

75. Song JH, Park MH, Han C, Jo SA, Ahn K. Serum Homocysteine and Folate Levels are Associated With Late-life Dementia in a Korean Population. Osong Public Heal Res Perspect. 2010;1(1):17-22.

76. Seshadri S, Beiser A, Selhub J, Jacques PF, Rosenberg IH, D'Agostino RB, et al. Plasma Homocystreine as a Risk Factor for Dementia and Alzheimer's Disease. N Engl J Med. 2002;346(7):476-83.

77. Price BR, Wilcock DM, Weekman EM. Hyperhomocysteinemia as a Risk Factor for Vascular Contributions to Cognitive Impairment and Dementia. Front Aging Neurosci. 2018;10:1-12

78. Wald DS, Kasturiratne A, Simmonds M. Serum homocysteine and dementia: Meta-analysis of eight cohort studies including 8669 participants. Alzheimer's Dement. 2011;7(4):412-7.

79. Farina N, Jernerén F, Turner C, Hart K, Tabet N. Homocysteine concentrations in the cognitive progression of Alzheimer's disease. Exp Gerontol. 2017;99: 146-50.

80. Reynolds E. Vitamin $B_{12}$, folic acid and the nervous system. Lancet Neurol. 2006;5(11):949-60.

81. Pawlak R, Parrott SJ, Raj S, Cullum-Dugan D, Lucus D. How prevalent is Vitamin $B_{12}$ deficiency among vegetarians?. Nutr Rev. 2013;71(2):110-7.

82. Flood VM, Smith WT, Webb KL, Rochtchina E, Anderson VE, Mitchell P. Prevalence of low serum folate and Vitamin B12 in an older Austaralian population. Aust N Z J Public Health. 2006;30(1):38-41.

83. Clarke R, Birks J, Nexo E, Ueland PM, Schneede J, Scott J, et al. Low Vtamin $B_{12}$ status and risk of cognitive decline in older adults. Am J Clin Nutr. 2007;86(5):1384-91.

84. Duthie SJ, Whalley LJ, Collins AR, Leaper S, Berger K, Deary IJ. Homocys- teine, B vitamin status and cognitive function in the elderly. Am J Clin Nutr. 2002;75(5):908-13.

85. Riggs KM, Spiro III A, Tucker K, Rush D. Relations of Vitamin $B_{12}$, homocysteine to cognitive Aging Study. Am J Clin Nutr. 1996;63(3):306-14

86. Fripp J, Bourgeat $\mathrm{P}$, Acosta O, Raniga P, Modat M, Pike KE, et al. Appearance modeling of $11 \mathrm{C} \mathrm{PiB} \mathrm{PET} \mathrm{images:} \mathrm{Characterizing} \mathrm{amyloid} \mathrm{deposition} \mathrm{in}$ Alzheimer's disease, mild cognitive impairment and healthy aging. Neuroimage. 2008;43(3):430-9.

87. Seal EC, Metz J, Flicker L, Melny J. A Randomized, Double-Blind, PlaceboControlled Study of Oral Vitamin $B_{12}$ Supplementation in Older Patients with Subnormal or Borderline Serum Vitamin $B_{12}$ Concentrations. J Am Geriatr Soc. 2002;50(1):146-51.

88. Leary FO, Allman-farinelli M, Samman S. Vitamin $B_{12}$ status, cognitive decline and dementia: a systematic review of prospective cohort studies. $\mathrm{Br} \mathrm{J}$ Nutr. 2012;108(11):1948-61.

89. Eyles DW, Smith S, Kinobe R, Hewison M, Mcgrath JJ. Distribution of the Vitamin D receptor and 1a-hydroxylase in human brain. J Chem Neuroanat. 2005;29(1):21-30.

90. Littlejohns TJ, Henley WE, Lang IA, Annweiler C, Fried L, Kestenbaum BR, et al. Vitamin $\mathrm{D}$ and the risk of dementia and Alzheimer disease. Neurology. 2014;83(10):920-8.

91. Mokry LE, Ross S, Morris JA, Manousaki D. Genetically decreased Vitamin D and risk of Alzheimer disease. Neurology. 2016;87(24):2567-74.

92. Mcgrath J, Scragg R, Chant D, Eyles D, Burne T, Obradovic D. No Association between Serum 25-Hydroxyvitamin D3 Level and Performance on Psychometric Tests in NHANES III. Neuroepidemiology. 2007;29(1-2):49-54.

93. Buschert V, Bokde ALW, Hampel H. Cognitive intervention in Alzheimer disease. Nat Rev Neurol. 2010;6(9):50817.

94. Reijnders J, Heugten CV, Boxtel MV. Cognitive interventions in healthy older adults and people with mild cognitive impairment: A systematic review. Ageing Res Rev. 2013;12(1):263-75.

95. Jiang L, Cao X, Li T, Tang Y, Li W, Wang J, et al. Cortical Thickness Changes Correlate with Cognition Changes after Cognitive Training: Evidence from a Chinese Community Study. Front Aging Neurosci. 2016;8:118.

96. Bamidis PD, Fissler P, Papageorgiou SG, Zilidou V, Konstantinidis EI ,Billis AS, et al. Gains in cognition through combined cognitive and physical training: The role of training dosage and severity of neurocognitive disorder. Front Aging Neurosci. 2015;7:152.

97. Tagliabue CF, Guzzetti S, Gualco G, Boccolieri G, Boccolieri A, Smith S, et al. A group study on the effects of a short multi-domain cognitive training in healthy elderly Italian people. BMC Geriatr. 2018;18(1):321.

98. Cheng $Y$, Wu W, Feng W, Wang J, Chen $Y$, Shen $Y$, et al. The effects of multidomain versus single-domain cognitive training in non-demented older people: a randomized controlled trial. BMC Med. 2012;10(1):30.

99. Kelly ME, Loughrey D, Lawlor BA, Robertson IH, Walsh C, Brennan S. The impact of cognitive training and mental stimulation on cognitive and everyday functioning of healthy older adults: A systematic review and meta-analysis. Ageing Res Rev. 2014;15:28-43.

100. Ball K, Berch DB, Helmers KF, Jobe JB, Leveck MD, Marsiske M, et al. Effects of Cognitive Training Interventions With Older Adults: A Randomized Controlled Trial. J Am Med Assoc. 2002;288(18):2271-81.

101. Chodzko-Zajko WJ, Proctor DN, Singh MAF, Minson CT, Nigg CR, Salem GJ, et al. Exercise and Physical Activity for Older Adults. Med Sci Sport Exerc 2009;41(7):1510-30.

102. Scarmeas N, Luchsinger JA, Cosentino S, Schupf N, Xin-tang M, Gu Y, et al. Physical Activity and Alzheimer Disease Course. Am J Geriatr Psychiatry 2011;19(5):471-81.

103. Chang M, Jonsson PV, Snaedal J, Bjornsson S, Saczynski JS, AspelundT, et al. The Effect of Midlife Physical Activity on Cognitive Function Among Older Adults: AGES-Reykjavik Study. Journals Gerontol Ser A Med Sci. 2010;65A(12):1369-74.

104. Andel R, Crowe M, Pedersen NL, Fratiglioni L, Johansson B, Gatz M. Physical Exercise at Midlife and Risk of Dementia Three Decades Later: A PopulationBased Study of Swedish Twins. Journals Gerontol Ser A Gerontol Med Sci. 2008;63A(1):62-6.

105. Palta P, Sharrett AR, Deal JA, Evenson KR, Gabriel KP, Folsom AR, et al. Leisure-time physical activity sustained since midlife and preservation of cognitive function: The Atherosclerosis Risk in Communities study cohort. Alzheimer's Dement. 2019;15(2):273-81.

106. Krell-Roesch J, Feder NT, Roberts RO, Mielke MM, Christianson TJ, Knopman DS, et al. Leisure-Time Physical Activity and the Risk of Incident Dementia: The Mayo Clinic Study of Aging. J Alzheimer's Dis. 2018;63(1):149-55.

107. Willey JZ, Gardener H, Caunca MR, Moon YP, Sacco RL, Elkind MS V, et al. Leisure-time physical activity associates with cognitive decline: The Northern Manhattan Study. Neurology. 2016;86(20):1897-903.

108. Erickson KI, Prakash RS, Voss MW, Chaddock L, Hu L, Morris KS, et al. Aerobic Fitness is Associated With Hippocampal Volume in Elderly Humans. Hippocampus. 2009;19(10):1030-9.

109. Barreto PDS, Demougeot $L$, Vellas $B$, Rolland $Y$. Exercise training for preventing dementia, mild cognitive impairment and clinically meaningful cognitive 
decline: A systematic review and meta-analysis Philipe. Journals Gerontol Ser A. 2018;73(11):1504-11.

110. Young J, Angevaren M, Rusted J, Tabet N. Aerobic exercise to improve cognitive function in older people without known cognitive impairment. Cochrane Database Syst Rev. 2015;(4):CD005381.

111. Zhou Z, Fu J, Hong YA, Wang P, Fang Y. Association between exercise and the risk of dementia: Results from a nationwide longitudinal study in China. BMJ Open. 2017;7(12):e017497.

112. Sink KM, Espeland MA, Castro CM, Church T, Cohen R, Dodson JA, et al. Effect of a 24-Month Physical Activity Intervention vs Health Education on Cognitive Outcomes in Sedentary Older Adults: The LIFE Randomized Trial. J Am Med Assoc. 2015;314(8):781-90.

113. Lautenschlager NT, Cox KL, Flicker L, Foster JK, Bockxmeer FMV, Xiao J, et al. Effect of Physical Activity on Cognitive Function in Older Adults at Risk for Alzheimer Disease. J Am Med Assoc. 2008;300(9):1027-37.

114. Gross AL, Lu H, Meoni L, Gallo JJ, Schrack JA, Sharett RA. Physical Activity in Midlife is not Associated with Cognitive Health in Later Life Among Cognitively Normal Older Adults. J Alzheimer's Dis. 2017:59(4):1349-58.

115. Tan ZS, Spartano NL, Beiser AS, Decarli C, Auerbach SH, Vasan RS, et al. Physical Activity, Brain Volume and Dementia Risk: The Framingham Study Editor's Choice. Journals Gerontol Ser A Biol Sci Med Sci. 2017;72(6):789-95.

116. Sabia S, Dugravot A, Abell J, Elbaz A, Singh-manoux A. Physical activity, cognitive decline and risk of dementia: 28 year follow-up of Whitehall II cohort study. BMJ. 2017;357:j2709.

117. Bruijn RFAG, Schrijvers EMC, DeGroot K, Witteman JCM, Hofman A, Franco OH, et al. The association between physical activity and dementia in an elderly population: The Rotterdam Study. Eur J Epidemiol. 2013;28(3):277-83.

118. Kishimoto H, Ohara T, Hata J, Ninomiya T, Yoshida D, Mukai N, et al. The longterm association between physical activity and risk of dementia in the community: The Hisayama Study. Eur J Epidemiol. 2016;31(3):267-74.

119. Buchman AS, Boyle PA, Yu L, Shah RC, Wilson RS, Bennett DA. Total daily physical activity and the risk of $A D$ and cognitive decline in older adults. Neurology. 2012;78(17):1323-9.

120. Vassilaki M, Aakre JA, Syrjanen JA, Mielke MM, Geda YE, Kremers WK, et al. Mediterranean diet, its components and amyloid imaging biomarkers. J Alzheimer's Dis. 2018;64(1):281-90.

121. Feart C, Samieri C, Rondeau V, Amieva H, Portet F, Dartigues JF, et al. Adherence to a Mediterranean Diet, Cognitive Decline and Risk of Dementia. J Am Med Assoc. 2009;302(6):638-48.

122. Tanaka T, Talegawkar SA, Jin Y, Colpo M, Ferrucci L, Bandinelli S. Adherence to a Mediterranean Diet Protects from Cognitive Decline in the Invecchiare in Chianti Study of Aging. Nutrients. 2018;10(12):41317.

123. Wu L, Sun D. Adherence to Mediterranean diet and risk of developing cognitive disorders: An updated systematic review and meta-analysis of prospective cohort studies. Sci Rep. 2017;7:1-9.

124. Feart C, Samieri C, Barberger-Gateau P. Mediterranean diet and cognitive function in older adults. Curr Opin Clin Nutr Metab Care. 2010;13(1):14-8.

125. Anastasiou CA, Yannakoulia M, Kosmidis MH, Dardiotis E, Hadjigeorgiou GM, Sakka $\mathrm{P}$, et al. Mediterranean diet and cognitive health: Initial results from the Hellenic Longitudinal Investigation of Ageing and Diet. PLoS One 2017:12(8):e0182048.

126. Scarmeas N, Anastasiou CA, Yannakoulia M. Nutrition and prevention of cognitive impairment. Lancet Neurol. 2018;17:1006-15.

127. Qin B, Plassman BL, Edwards LJ, Popkin BM, Adair LS, Mendez MA. Fish Intake Is Associated with Slower Cognitive Decline in Chinese Older Adults. $J$ Nutr. 2014;144(10):1579-85.

128. Huang T, Zandi P, Tucker KL, Fitzpatrick A, Kuller L, Fried L, et al. Benefits of fatty fish on dementia risk are stronger for those without APOE $\varepsilon 4$. Neurology. 2005;65(9):1409-14

129. Morris MC, Evans DA, Tangney CC, Bienias JL, Wilson RS. Fish Consumption and Cognitive Decline With Age in a Large Community Study. Arch Neurol. 2005;62(12):1849-53.

130. DeRest OV, Geleijnse J, Staveren WW, Dullermeijer C, OlderRikkert $M$, Beekman A, et al. Effect of fish oil on cognitive performance in older subjects A randomized, controlled trial. Neurology. 2008;71(6):430-8.

131. Morris MC, Wang Y, Barnes LL, Bennett DA, Dawson-Hughes B, Booth SL. Nutrients and bioactives in green leafy vegetables and cognitive decline. Neurology. 2018;90(3):e1-9.

132. Yuan C, Fondell E, Bhushan A, Ascherio A, Okereke OI, Grodstein F, et al. Longterm intake of vegetables and fruits and subjective cognitive function in US men. Neurology. 2019;92(1):1-13.

133. Morris M, Evans D, Tangney C, Bienias J, Wilson R. Associations of vegetable and fruit consumption with age-related cognitive change. Neurology. 2006;67(8):1370-6.

134. Dai Q, Borenstein AR, WuY, Jackson JC, Larson EB. Fruit and Vegetable Juices and Alzheimer's Disease: The Kame Project. Am J Med. 2006;119(9):751-9.

135. Devore EE, Kang JH, Breteler MMB, Grodstein F. Dietary intake of berries and flavonoids in relation to cognitive decline. Ann Neurol. 2012;72(1):135-43.

136. Gu Y, Brickman AM, Stern Y, Habeck CG, Manly JJ, Schupf N, et al. Mediterranean diet and brain structure in a multiethnic elderly cohort. Neurology. 2015;85(20):1744-51.

137. Galbete C, Schwingshackl L, Schwedhelm C, Schulze MB. Evaluating Mediterranean diet and risk of chronic disease in cohort studies: An umbrella review of meta-analyses. Eur J Epidemiol. 2018;33(10):909-31.

138. Vercambre MN, Grodstein F, Berr C, Kang JH. Mediterranean diet and cognitive decline in women with cardiovascular disease or risk factors. J Acad Nutr Diet. $2012 ; 112(6): 816-23$.

Article History: Submission Date : 02-05-2019; Revised Date : 28-05-2019; Acceptance Date : 29-06-2019.

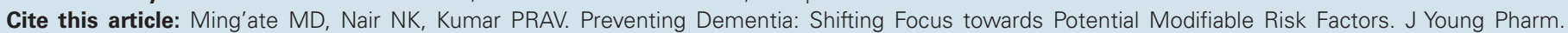
2019;11(3):230-7. 